University of Nebraska - Lincoln

DigitalCommons@University of Nebraska - Lincoln

Economics Department Faculty Publications

Economics Department

July 2008

\title{
Smoke-Free Laws and Employee Turnover
}

Eric C. Thompson

University of Nebraska-Lincoln, ethompson2@unl.edu

Ellen J. Hahn

University of Kentucky, Lexington, $K Y$, ejhahn00@email.uky.edu

Glenn Blomquist

University of Kentucky, Lexington, KY, gcblom@email.uky.edu

John Garen

University of Kentucky, Lexington, $K Y$, jgaren@email.uky.edu

Don Mullineaux

University of Kentucky, Lexington, $K Y$

See next page for additional authors

Follow this and additional works at: https://digitalcommons.unl.edu/econfacpub

Part of the Economics Commons

Thompson, Eric C.; Hahn, Ellen J.; Blomquist, Glenn; Garen, John; Mullineaux, Don; Ogunro, Nola; and Rayens, Mary K., "Smoke-Free Laws and Employee Turnover" (2008). Economics Department Faculty Publications. 26.

https://digitalcommons.unl.edu/econfacpub/26

This Article is brought to you for free and open access by the Economics Department at DigitalCommons@University of Nebraska - Lincoln. It has been accepted for inclusion in Economics Department Faculty Publications by an authorized administrator of DigitalCommons@University of Nebraska - Lincoln. 


\section{Authors}

Eric C. Thompson, Ellen J. Hahn, Glenn Blomquist, John Garen, Don Mullineaux, Nola Ogunro, and Mary K. Rayens 
Published in Contemporary Economic Policy 26:3 (July 2008), pp. 351-359; doi 10.1111/j.1465-7287.2007.00091.x Copyright (c) 2008 Western Economic Association International; published by Blackwell Publishing/John Wiley \& Sons., Inc. http://www.interscience.wiley.com/jpages/1074-3529 Used by permission.

Published online January 16, 2008

The authors gratefully acknowledge the comments of two anonymous referees for CEP and the financial assistance of The Robert Wood Johnson Foundation Substance Abuse Policy Research Program.

\title{
Smoke-Free Laws and Employee Turnover
}

\author{
Eric Thompson, ${ }^{1}$ Ellen J. Hahn, ${ }^{2}$ Glenn Blomquist, ${ }^{3}$ John Garen, ${ }^{4}$ \\ Don Mullineaux, ${ }^{5}$ Nola Ogunro, ${ }^{6}$ and Mary K. Rayens ${ }^{7}$
}

${ }^{1}$ Thompson - Associate Professor of Economics, Department of Economics, University of Nebraska-Lincoln, Lincoln, NE 68588; email ethompson2@unl.edu

${ }^{2}$ Hahn - Professor, School of Nursing, University of Kentucky, Lexington, KY 40506; email ejhahn00@uky.edu

${ }^{3}$ Blomquist - Pollard Endowed Professor of Economics, Department of Economics, University of Kentucky, Lexington, KY 40506; email gcblom@uky.edu

${ }^{4}$ Garen - Gatton Endowed Professor of Economics, Department of Economics, University of Kentucky, Lexington, KY 40506; email jgaren@uky.edu

${ }^{5}$ Mullineaux - duPont Endowed Chair in Banking and Professor of Finance, Department of Finance, University of Kentucky, Lexington, KY 40506; email mullinea@uky.edu

${ }^{6}$ Ogunro - Graduate Student in Economics, University of Kentucky, Lexington, KY 40506; email nogun2@uky.edu

${ }^{7}$ Rayens - Associate Professor, School of Nursing, University of Kentucky, Lexington, KY 40506; email mkrayens@uky.edu

\begin{abstract}
:
This study examines how smoke-free laws influence turnover among restaurant workers. The study uses a unique data set of payroll records of a franchisee of a national full-service restaurant chain operating 23 restaurants in the state of Arizona, a state where several communities have adopted smoke-free laws. Municipal smoke-free laws did not, on average, have a statistically significant effect on the probability of employee separation in the years after implementation. These results suggest that training costs associated with employee turnover would not rise for full-service restaurants in municipalities that adopt smoke-free laws.
\end{abstract}

\section{Introduction}

While health and safety regulations are often set at the state and federal level, many local jurisdictions also have the power to enact workplace regulations. In particular, there is a growing trend toward local regulation of workplace smoking. Today, nearly 570 local municipalities and 21 states plus the District of Columbia have enacted 100\% smoke-free laws in workplaces. Enacting the first local "clean indoor air" laws in 1973, Arizona led the way among states. These local workplace regulations have the potential to influence the aggregate level of industry activity, business costs, and labor market behavior of workers. This is particularly true of the bar and restaurant industries, and other recreation and entertainment industries, since business owners in these industries frequently choose to allow smoking.

Health advocates support local smoking ordinances as a public health strategy to enhance the safety of workplaces. ${ }^{1}$ But like all such safety regu- lations, including safety regulations at construction sites, mines, or manufacturing plants, smoke-free laws have potential to introduce economic inefficiencies. Free from safety regulation, workers may choose to trade workplace safety for higher wages or other desirable features of a job. Minimum safety standards cause some workers to accept something less than what they would consider an optimal mix of safety, wages, and other employment features (Pakko, 2005). One implication is that the introduction of a smoke-free law may cause some workers to leave employment at bar and restaurant businesses in municipalities with smoke-free laws, although the introduction also may encourage other workers to seek employment.

1. Bar and restaurant workers' exposure to secondhand tobacco smoke is 1.5-4.4 times greater than that of individuals living with smokers (Siegel, 1993). For evidence that passive smoking causes coronary heart disease, lung cancer, and various respiratory ailments (see U.S. Department of Health and Human Services, 2006; Law and Wald, 2003; Wells, 1998). Passive smokers also experience other health conditions including eye irritation, headaches, nasal symptoms, coughs, wheezing, and hoarseness (Wakefield et al., 2003). 
Recent literature has examined the influence of smoke-free laws in terms of customer demand to patronize businesses in the hospitality industry (Corsun, Young, and Enz, 1996; Glantz and Smith, 1997; Hyland, Cummings, and Nauenberg, 1999; Pakko, 2005). Other recent literature has measured private market provision of smoke-free environments to accommodate consumer preferences and the differential effect of smoke-free laws on restaurant and bar profitability (Dunham and Marlow, 2000, 2003, 2004). The purpose of this study was to examine how laws influence employee turnover, which is a key determinant of operating cost for the industry. We examine whether the likelihood of employee separation from a job at a full-service restaurant is influenced by the introduction or presence of a local smoke-free law, after controlling for other factors that influence employee separation.

\section{Methodology}

The likelihood of a worker separating from their job falls with tenure as workers learn more about the rewards and conditions of a particular job and employers learn more about the performance of workers (Bartel and Borjas, 1977; Jovanovic, 1979; Viscusi, 1980). Personal characteristics such as education, age, health, and sex further influence the likelihood of separation (Bartel and Borjas, 1977; Meitzen, 1986; Mincer and Jovanovic, 1981; Royalty, 1998).

The introduction of a smoke-free law also could influence the match between an existing worker and their job. The law may represent a shock to the "match" for existing workers, leading to an increase in separation rates. While many workers may prefer to work in a smoke-free workplace, other job attributes such as earnings from tips also may change as a municipal smoke-free law is implemented. Dunham and Marlow (2003) note that restaurants negatively impacted by smoke-free laws are more likely to increase job responsibilities for their workers. Some existing workers may find the new bundle of job attributes inferior to the previous arrangement. This is particularly true of any group workers, such as workers who smoke, who may have found a smoking-allowed work environment to be an amenity.

The long-run effects of smoke-free laws on employee separation rates are less clear, however. Over the long run, there is turnover in staff. The match be- tween new workers and their employers develop in the smoke-free environment, so that the smoke-free law does not represent any shock to the match. The employee separation rate in the long run could be higher, lower, or no different for restaurants in municipalities with smoke-free laws.

In this study we use a panel data set with treatment and control groups to examine the influence of local smoke-free laws on employee separations. A logistic regression of employee separation was estimated using data on employees of a franchiser of a national restaurant chain operating in the state of Arizona over a 5-year period. The chain operates full-service restaurants serving alcohol, with seating for an average of 190 customers, and offering mid-price meals. Dunham and Marlow (2000, 2003) note that the introduction of smoke-free laws has a varying impact on different segments of the restaurant industry. Profitability is most impacted in restaurants with more seating, a larger share of sales from alcohol, and a larger share of seating in the smoking-allowed section but is not impacted by whether a restaurant is part of a chain or independent. ${ }^{2}$ The restaurants we examine, with large seating capacity and alcohol sales, have the characteristics of restaurants likely to be impacted by smoke-free laws.

The panel data set included payroll records available for two-week pay periods for employees of 23 Arizona restaurants from April 1999 to April 2004 (see Table 1), as well as employee characteristics such as age, race, gender, and occupation. Each 2wk employee pay period served as a single observation. The restaurant franchiser allowed smoking at its restaurants in the absence of a municipal smokefree law. Of the 23 restaurants, 12 were located in municipalities with a smoke-free law as of 2004. Presence of a smoke-free ordinance was obtained from the Americans for Nonsmokers' Rights database (http://www.no-smoke.org) and confirmed with the company management.

Three of the restaurants opened smoke free (one in Tucson, one in Mesa, and one in Gilbert). The smoke-free ordinance in Mesa also was implemented before April 1999, so that our database for the Mesa restaurants only contained observations for workers in the period after the smoke-free law was in effect. Six remaining restaurants were in

2. Dunham and Marlow (2004) report that chain restaurants offered more space for nonsmoking seating. 
Table 1. Statistics for Arizona Restaurants.

\begin{tabular}{|c|c|c|c|}
\hline Location & Opened & County & $\begin{array}{l}\text { Date Community } \\
\text { Went Smoke Free }\end{array}$ \\
\hline \multicolumn{4}{|c|}{ Restaurants in communities with smoke-free laws as of 2004} \\
\hline $\begin{array}{l}\text { Mesa, Arizona (1) } \\
\text { Mesa, Arizona (2) } \\
\text { Mesa, Arizona (3) } \\
\text { Mesa, Arizona (4) } \\
\text { Tempe, Arizona (1) } \\
\text { Tempe, Arizona (2) } \\
\text { Chandler, Arizona } \\
\text { Gilbert, Arizona } \\
\text { Tucson, Arizona (1) } \\
\text { Tucson, Arizona (2) } \\
\text { Tucson, Arizona (3) } \\
\text { Tucson, Arizona (4) }\end{array}$ & $\begin{array}{l}\text { December } 1992 \\
\text { November } 1992 \\
\text { June } 1993 \\
\text { November } 1998 \\
\text { June } 1994 \\
\text { April } 1997 \\
\text { November } 1997 \\
\text { May } 2002 \\
\text { September } 1991 \\
\text { May } 1994 \\
\text { March } 1997 \\
\text { January } 2000\end{array}$ & $\begin{array}{l}\text { Maricopa } \\
\text { Maricopa } \\
\text { Maricopa } \\
\text { Maricopa } \\
\text { Maricopa } \\
\text { Maricopa } \\
\text { Maricopa } \\
\text { Maricopa } \\
\text { Pima } \\
\text { Pima } \\
\text { Pima } \\
\text { Pima }\end{array}$ & $\begin{array}{l}\text { July } 1996 \\
\text { July } 1996 \\
\text { July } 1996 \\
\text { July } 1996 \\
\text { May } 2000 \\
\text { May } 2000 \\
\text { October } 2003 \\
\text { May } 2001 \\
\text { October } 1999 \\
\text { October } 1999 \\
\text { October } 1999 \\
\text { October } 1999\end{array}$ \\
\hline \multicolumn{4}{|c|}{ Restaurants in communities without smoke-free laws as of 2004} \\
\hline $\begin{array}{l}\text { Phoenix, Arizona (1) } \\
\text { Phoenix, Arizona (2) } \\
\text { Phoenix, Arizona (3) } \\
\text { Phoenix, Arizona (4) } \\
\text { Peoria, Arizona } \\
\text { Scottsdale, Arizona } \\
\text { Prescott, Arizona } \\
\text { Glendale, Arizona } \\
\text { Goodyear, Arizona } \\
\text { Surprise, Arizona } \\
\text { Sierra Vista, Arizona }\end{array}$ & $\begin{array}{l}\text { December } 1992 \\
\text { May } 1995 \\
\text { October } 1995 \\
\text { June } 2002 \\
\text { September } 1993 \\
\text { December } 1994 \\
\text { February } 1996 \\
\text { August } 1996 \\
\text { October } 2000 \\
\text { June 2001 } \\
\text { September } 2003\end{array}$ & $\begin{array}{l}\text { Maricopa } \\
\text { Maricopa } \\
\text { Maricopa } \\
\text { Maricopa } \\
\text { Maricopa } \\
\text { Maricopa } \\
\text { Yavapai } \\
\text { Maricopa } \\
\text { Maricopa } \\
\text { Maricopa } \\
\text { Cochise }\end{array}$ & $\begin{array}{l}\text { No } \\
\text { No } \\
\text { No } \\
\text { No } \\
\text { No } \\
\text { No } \\
\text { No } \\
\text { No } \\
\text { No } \\
\text { No } \\
\text { No }\end{array}$ \\
\hline
\end{tabular}

municipalities that were not smoke free in April 1999, but then implemented a smoke-free law later either in October 1999 (Tucson), May 2000 (Tempe), or in October 2003 (Chandler). Given the relatively short tenure of restaurant workers (see Table 2), the 7 months of pre-ban data for workers in Tucson restaurants and 12 months in Tempe are sufficient for pre-ban and post-ban comparisons of separation rates within restaurants.

The two treatment groups used in the analysis included restaurant payroll records during any period when a restaurant operated under a local smokefree law. Treatment Group I included 14,927 postban payroll records from employees who worked at a restaurant both before and after the municipality where the restaurant was located implemented a smoke-free law. For these workers, the introduction of a smoke-free law represented a potential "shock" to their work situation. Treatment Group II included 69,966 payroll records for employees who worked at a restaurant only after the restaurant's munici- pality implemented a smoke-free law. ${ }^{3}$ The control group in the analysis consisted of restaurant payroll records during any period when the restaurant did not face a local smoke-free law, either because the municipality where the restaurant was located never had a smoke-free law or because the law was not yet in effect. There were 90,810 payroll records in the control group.

Age, gender, ethnicity, job tenure, occupation, and separation date were obtained from company payroll system records. The payroll database did not include data on other personal characteristics of workers that could influence employee separation rates, such as education level and marital status, or other factors that could influence worker reaction to a municipal smoke-free ordinance, such as smoking

3. Therefore, Treatment Group II included payroll records for employees of the three restaurants that opened smoke free, and employees of the nine restaurants in Treatment Group I who started working there only after the restaurant became smoke free. 
Table 2. Summary Statistics.

\begin{tabular}{|c|c|c|}
\hline Variable & Mean & Standard Deviation \\
\hline \multicolumn{3}{|c|}{ Probability of separation and tenure } \\
\hline \multicolumn{3}{|c|}{ \% separating during } \\
\hline the pay period & 4.2 & 20.0 \\
\hline Tenure (d) & 539 & 632 \\
\hline Tenure squared (d) & 685.343 & $1,603,303$ \\
\hline \multicolumn{3}{|l|}{ Personal characteristics } \\
\hline \multicolumn{3}{|l|}{ Gender (\%) } \\
\hline Male & 47.8 & 50.0 \\
\hline Female & 52.2 & 50.0 \\
\hline Age (years) & 26.1 & 7.0 \\
\hline \multicolumn{3}{|l|}{ Race (\%) } \\
\hline White & 71.4 & 45.2 \\
\hline Black & 3.0 & 17.1 \\
\hline Hispanic & 20.3 & 40.2 \\
\hline \multicolumn{3}{|l|}{ American Indian/Alaska } \\
\hline Native & 1.2 & 11.0 \\
\hline Asian/Pacific Islander & 0.1 & 2.9 \\
\hline Not specified & 4.0 & 19.5 \\
\hline \multicolumn{3}{|l|}{ Occupation (\%) } \\
\hline Server & 54.8 & 49.8 \\
\hline Hostess & 17.1 & 37.6 \\
\hline Bartender & 2.0 & 13.9 \\
\hline Kitchen & 24.3 & 42.9 \\
\hline All other occupations & 1.8 & 13.4 \\
\hline
\end{tabular}

behavior. Observations were available for each 2-wk pay period for the entire employment period. Separation was assumed to occur at the date of each worker's last entry in the payroll record. Of the approximately 9,300 workers in the payroll database, roughly one-third were still employed with the franchiser at the end of the data set.

The first model pooled observations from members of Treatment Group I, Treatment Group II, and the control group. This model examined the impact of a smoke-free law on the probability of separation for all restaurant employees after a smoke-free law was in effect, regardless of when the workers began working at the restaurants. A variable indicating whether each employee's place of work operated under a smoke-free law in a particular pay period was assigned a value of 1 for all members of either Treatment Group I or II and a value of 0 for all members of the control group. The probability of separation for employees in any particular period was modeled as a function of an employee's job tenure, job tenure squared, and personal character- istics (age, gender, and race/ethnicity), as well as a variable indicating the presence of a smoke-free law. There also was a dummy variable for each restaurant to control for idiosyncratic working conditions, and a dummy variable for each month-year from April 1999 through April 2004 to account for season and business cycle impacts. Some employees had two employment spells at a restaurant, and each spell was treated as separate members of the panel. A dummy variable was used to indicate the second employment spell. In the logistic regression, standard errors were adjusted for clustering on employee-specific identification numbers.

The second model pooled Treatment Group I with the control group. The third model pooled Treatment Group II with the control group. For all three models, we present coefficient estimates from the logistic regression as well as estimates of each variable's marginal effect.

Models 1 through 3 contain a single dummy variable indicating that an employee works at a restaurant in a municipality covered by a smokefree law during a particular pay period. Coefficient estimates for the dummy variable indicate that the average effect of a smoke-free law on employee turnover in the years after the law is in effect. The models, however, do not capture how the effect of smoke-free laws may vary over time. In particular, such a law may have a differential effect in the first few months it is in effect relative to the longer term. It is in this initial period when most existing workers are facing a shock to working condition in regards to secondhand smoke in the workplace. In the longer run, as there is a natural turnover in restaurant staff, most workers will have joined the staff after the municipal smoke-free law was in place. The long-run effect, if any, could differ from the initial effect.

We tested for this possibility by developing an additional model. In this fourth model, we use the full sample from the first model (both the treatment groups and the control group) and replace the single dummy variable indicating that the smoke-free law is in effect with a set of 13 dummy variables, which indicate the amount of time that had passed since the law went into effect. The first dummy indicates that the smoke-free law was in effect for one quarter or less; the second dummy indicates that the law was in effect from 4 to 6 months (i.e., the second quarter after the law went into effect). There are 12 such dummy variables for the first 12 quarters 
the law is in effect, and a final dummy variable indicating that the law had been effect for more than 3 years.

\section{Results}

Table 2 presents summary statistics for the workers in this sample. On average, $4.2 \%$ of workers separated from employment during a single 2-wk pay period. The average tenure of workers at any time during the 5-year period was 539 days, which is roughly 1.5 years. More than half of the employees were female. More than $70 \%$ of workers were white, while roughly $20 \%$ were Hispanic and 3\% were African American. The average age of workers was 26 years (standard deviation $=7$ years). More than half of the workers were employed as servers, about one-quarter as kitchen workers, onesixth as hosts, and a fraction as bartenders or other occupations.

Coefficient estimates from the logistic regression are presented in Table 3, along with estimates on the marginal effect of each variable on the probability of separation. The marginal effects are estimated at the mean value for all variables. Coefficients for individual month and restaurant dummies are not reported for brevity but are available from the first author upon request.

Results for all workers in Table 3 are for the case where Treatment Group I, Treatment Group II, and the control group were pooled. The treatment group contains pay period observations for all workers at a restaurant operating under a smoke-free law, regardless of whether they joined the restaurant before (Treatment Group I) or after (Treatment Group II) the smoke-free law went into effect.

Results for existing workers were for the case where Treatment Group I and the control group were pooled. The treatment group contains pay period observations for workers at a restaurant operating under a smoke-free law but who joined the restaurant staff before the law was implemented. Results for new workers were for the case when Treatment Group II and the control group were pooled. The treatment group contains pay period observations for workers who joined the restaurant staff only after the smoke-free law was in effect.

In all three regressions, the probability of separation fell with tenure in the job. At mean values for tenure and tenure squared, the marginal effect of additional days of tenure reduced the probability of separation. Further, re-estimates of the marginal effects at higher levels of tenure (such as tenure $=$ 2,000 days and tenure squared $=4,000,000$ days) indicated that the marginal effect of additional days of tenure would remain negative. Thus, the relationship between the greater tenure and the probability of separation was negative even for an average tenure of more than 5 years (2000 days is roughly 5.5 years).

The probability of separation also was lower for workers in their second spell of employment at a restaurant in both the all workers and the new workers regression. This could have occurred because workers in their second spell were more familiar with the requirements of the job and managers also were more familiar with the workers. No statistically significant difference was found in the existing workers regression, but this may have simply reflected the smaller sample size available.

The probability of separation was related to ethnicity in all three regressions. Relative to white workers, the probability of separation was lower for Hispanic workers. Gender was not related to the probability of separation in any of the three regressions. In all three regressions, the probability of separation was lower for other occupations than for the omitted category, kitchen workers. This makes sense because the other occupations category includes managers who have longer tenure. The probability of separation also was lower for bartenders in two of the three regressions.

Finally, in all three regressions, no statistically significant relationship was found between the presence of a smoke-free law and the probability of employee separation. The coefficient on the "law in effect" variable is not statistically significant in any of the regressions. This implies that there is no effect, on average, on the probability of separation in the years after a smoke-free law is adopted by a municipality. This finding, however, does not preclude an effect in the initial periods after the smoke-free law is adopted when the law provides an initial shock to the working conditions of existing restaurant workers. For example, there could be an initial increase in separation rates for existing workers after the law is implemented, but several years later, the long-run separation rate (for workers who joined the restaurant after the law was 


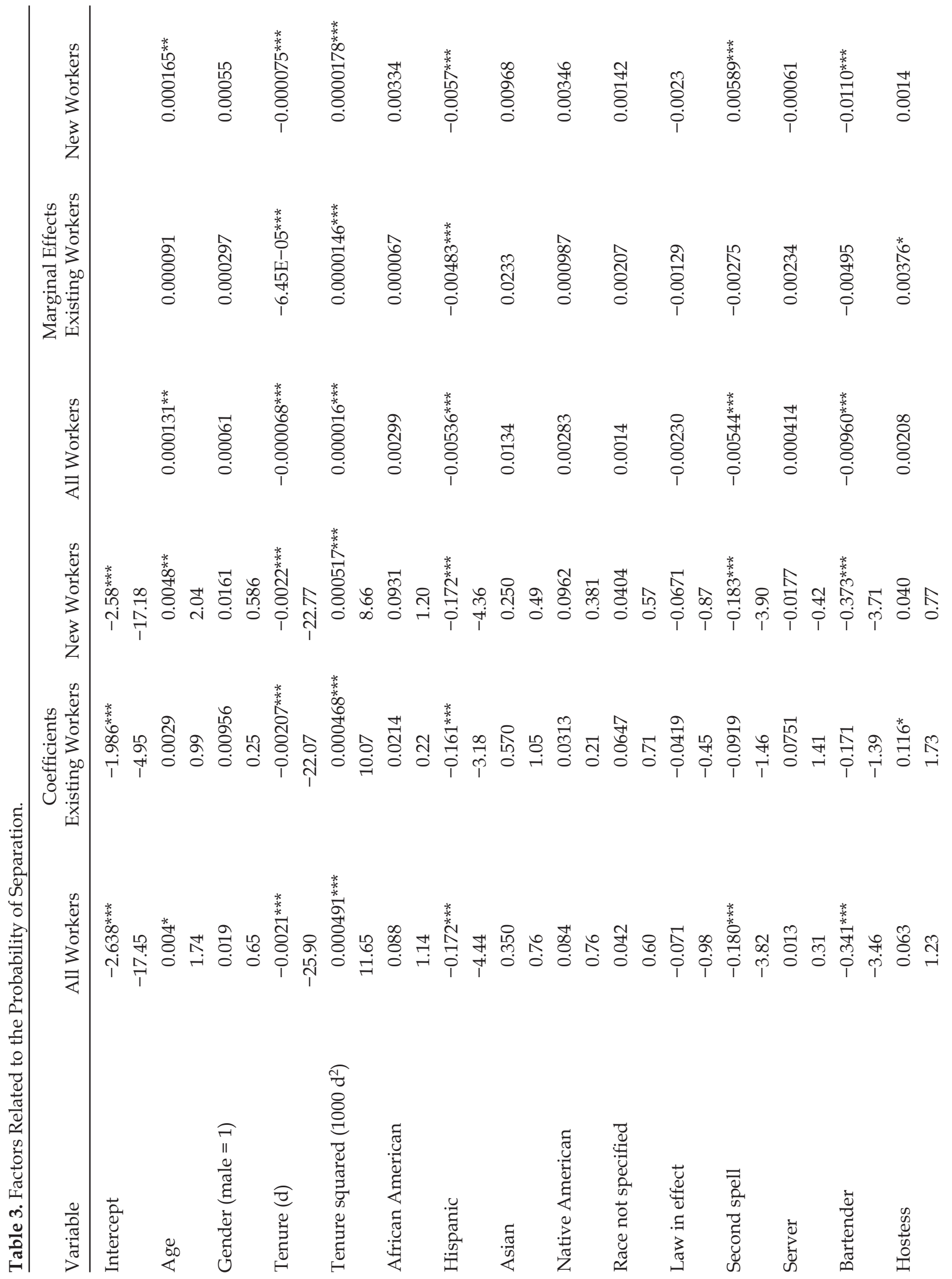


implemented) may be lower in municipalities with smoke-free laws. The effect of the smokefree law on separation rates varies through time, but the average effect is zero.

To test this possibility, we estimated a fourth regression, where the "law in effect" variable from the all workers regression was replaced with 13 dummy variables indicating the length of time that a municipal smoke-free law had been in effect. Joint significance tests indicated that the coefficients on these 13 dummy variables were not jointly different from zero. This suggests that there was no significant effect on separation rates through time, just as no average effect was identified in Table 3 .

Coefficients for several individual dummy variables were significant, however. In Figure 1, we present the individual estimates from this regression for these 13 dummy variables. In particular, we show the estimated marginal effect for each of the 12 quarterly dummy variables and the 13th variable indicating that the smoke-free law had been effect for more than 3 years.

There is a statistically significant decline in the separation rate for workers in first quarter after the smoke-free law is implemented. ${ }^{4}$ In other words, workers are less likely to separate from their job in the first few months the law was in effect. Point estimates remain negative throughout the first eight quarters that the law was in effect, and the negative marginal effect is statistically significant in the sixth quarter. Point estimates alternate between negative and positive values beginning with the ninth quarter and are not statistically significant. These quarterly results do not show a consistent impact on separation rates.

Over the longer run, we did not find evidence of a relationship between municipal smoke-free laws and separation rates. There was no statistically significant relationship between the introduction of municipal smokefree laws and the probability of separation beyond 18 months.

4. We also examined whether the probability of separation changed in the quarter before the local smoking ban was implemented, as workers anticipated the coming change. We did not find a statistically significant change in the chances of separation in the quarter before implementation. 


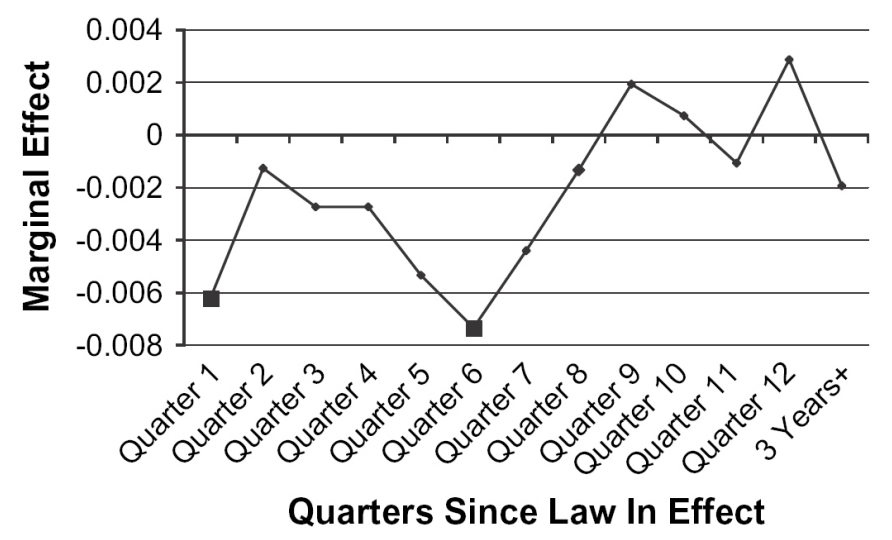

Figure 1. Marginal Effect of the Presence of a Local SmokeFree Law on the Probability of Separation. - indicates statistical significance at the $10 \%$ confidence level.

\section{Discussion and conclusions}

Previous economic research on smoke-free laws has focused on how these laws affect demand for businesses in the hospitality industry or on the differential effect of smoke-free laws on restaurant and bar profitability. The current study is an effort to examine how smoke-free laws influence the behavior of restaurant workers. In particular, we examined how adoption of municipal smoke-free laws influenced employee turnover, a key determinant of operating costs in the restaurant and bar industry. We used a unique data set of employment records of a franchiser of a national restaurant chain operating 23 full-service restaurants in the state of Arizona, a state where several municipalities have adopted smoke-free laws.

We found a statistically significant decline in the probability of separation in the initial months after a smoke-free law was implemented as well as evidence that separation rates were lower 16-18 months after implementation. However, there was no consistent pattern of either a decline or an increase in separation rates after the implementation of a smoke-free law. No average effect was identified in the years after implementation either for "existing" workers who were employed at the restaurant at the time of implementation or for "new" workers who joined the restaurant after implementation. While we found a statistically significant decline in separation rates in two quarters, the joint effect on separation rates across all quarters was not significantly different from zero. Further, there was no evidence of a relationship between smoke-free laws and employee separation beyond 18 months.

Taken together, these results suggest that municipal smoke-free laws did not change the separation rate for workers in the long run. The laws also did not induce an increase in employee turnover in the initial period after implementation by disrupting the match between existing full-service restaurant workers and their employers. The latter result implies that in the quarters after the implementation of a smoke-free law, the change in bundle of working conditions - which could include changes in earnings from tips as well as the change in workplace smoking-did not increase the rate of separation among existing workers overall.

By contrast, the limited evidence we did find of a change in separation rates suggests that restaurant workers are for a period more likely to remain in their job after the implementation of a smoke-free law, perhaps experimenting with the new working conditions.

These aggregate results do not imply that municipal smoke-free laws have no impact on the welfare of restaurant workers. The mix of working conditions after the introduction of a smoke-free law may not match what many workers would have chosen in the absence of a regulation, even if the discrepancies did not appear to be large enough to drive up separation rates. Further, our analysis of aggregate separation rates may mask an increase in separation rates for some groups of workers, such as smokers. But it is important for business owners, who face the training costs associated with employee turnover, that the implementation of municipal smokefree laws did not lead to an increase in aggregate separation rates for restaurants of the franchiser we studied.

These restaurants, which provide mid-price meals and serve alcohol, are common throughout the United States. Several recent studies have indicated that larger restaurants serving alcohol are the types of restaurants whose profitability may be more likely to be affected by smoke-free laws (Dunham and Marlow, 2000, 2003). Findings regarding employee separation in these restaurants are therefore of general interest and do not merely represent a niche segment or lightly impacted portion of the industry. This said, it is not known whether the same effect (or lack of effect) on separation rates would be found in other restaurants that offer a different mix of services to a different customer base. 
Future research on employee separation rates needs to focus on workers in other segments of the restaurant industry.

Future research on separation rates may be able to identify the effect of laws on specific groups of workers, such as smokers. Such research also may be able to gather data on additional factors that influence employee separation, including employee education level and family structure, or major life changes faced by employees, such as graduation from high school or college.

\section{References}

Bartel, A. P., \& G. J. Borjas. Middle-Age Job Mobility: Its Determinants and Consequences, Men in the Pre-Retirement Years. Philadelphia: Temple University Press, 1977.

Corsun, D. L., C. A. Young, \& C. A. Enz. "Should NYC Restaurateurs Lighten Up? Effects of the City's Smoke-Free Air Act." Cornell Hotel and Restaurant Administration Quarterly, 37(2), 1996, 8-9.

Dunham, J., \& M. L. Marlow. "Smoking Laws and Their Differential Impacts on Restaurants, Bars, and Taverns." Contemporary Economic Policy, 18(3), 2000, 326-33.

Dunham, J., \& M. L. Marlow. "The Economic Incidence of Smoking Bans." Applied Economics, 35, 2003, 1935-42.

Dunham, J., \& M. L. Marlow. “The Private Market for Accommodation: Determinants of Smoking Policies in Restaurants and Bars." Eastern Economic Journal, 30, 2004, 377-91.

Glantz, S. A., \& L. R. A. Smith. "The Effect of Ordinances Requiring Smoke-Free Restaurants on Restaurant Sales: A Follow-Up." American Journal of Public Health, 87, 1997, 1687-93.
Hyland, A. K., M. Cummings, \& E. Nauenberg. “Analysis of Taxable Sales Receipts: Was New York City's Smoke-Free Air Act Bad for Restaurant Business?" Journal of Public Health Management and Practice, 5, 1999, 14-21.

Jovanovic, B. "Job Matching and the Theory of Turnover." Journal of Political Economy, 87, 1979, 972-90.

Law, M. R., \& N. J. Wald. “Environmental Tobacco Smoke and Ischemic Heart Disease." Progress in Cardiovascular Diseases, 46(1), 2003, 31-38.

Meitzen, M. E. “Differences in Male and Female Job-Quitting Behavior." Journal of Labor Economics, 4, 1986, 151-67.

Mincer, J., \& B. Jovanovic. Labor Mobility and Wages, Studies in Labor Markets. Cambridge, MA: National Bureau of Economic Research, 1981.

Pakko, M. R. On The Economic Impact of Smoking Bans. CRE8 Occasional Report No. 2005-2. Center for Regional Economics, St. Louis, MO: Federal Reserve Bank of St. Louis, 2005.

Royalty, A. "Job to Job and Job to Non-Employment Turnover by Gender and Education Level." Journal of Labor Economics, 16, 1998, 392-443.

Siegel, M. "Involuntary Smoking in the Restaurant Workplace: A Review of Employee Exposure and Health Effects." Journal of the American Medical Association, 270, 1993, 490-3.

U.S. Department of Health and Human Services. "The Health Consequences of Involuntary Exposure to Tobacco Smoke." Atlanta, GA: Department of Health and Human Services, Public Health Service, Centers for Disease Control and Prevention, National Center for Chronic Disease and Prevention and Promotion, Office of Smoking and Health, 2006.

Viscusi, W. K. "A Theory of Job Shopping: A Bayesian Perspective." Quarterly Journal of Economics, 94, 1980, 609-14.

Wakefield, M., L. Trotter, M. Cameron, A. Woodward, G. Inglis, \& D. Hill. "Association Between Exposure to Workplace Secondhand Smoke and Reported Respiratory and Sensory Symptoms: Cross-Sectional Study." Journal of Occupational and Environmental Medicine, 45, 2003, 622-7.

Wells, A. J. "Lung Cancer from Passive Smoking at Work." American Journal of Public Health, 88, 1988, 1025-29. 